\title{
Opportunities, Challenges and Pathways for the International Placement of Nurses from Bangladesh
}

\author{
Javed Mahmud \\ (DBA Program, Institute of Business Administration, University of Dhaka, Bangladesh)
}

\begin{abstract}
For a densely populated country like Bangladesh the international placement of professionals is an important source of revenue. This paper explores the opportunities that exist in the placement of Bangladeshi nurses in foreign countries. There is a considerable gap in the demand and supply of nurses in the world market. The Philippines and India are the leading 'exporters' of nurses globally. Nursing education commenced in Bangladesh more than 7 decades ago. However, a Global Value Chain (GVC) Analysis reveals that marketing is the weakest link in the international placement of nurses from Bangladesh, while the standard of the nursing schools are also not satisfactory. A Triple-triangle Analysis has also indicated a number of weaknesses at the firm internal, industry and macro levels. Interventions are required in the areas of financials support for student nurses, capacity development of nursing schools, promotion of Bangladesh as an 'exporter' of nurses, etc. to make it possible for Bangladesh to meet its own needs and supply nurses to the world in 5/10 years time.
\end{abstract}

Keywords: International placement, Bangladeshi nurses, GVC Analysis, Triple-triangle Analysis

\section{Introduction}

Bangladesh is the fifth most densely populated country in the world. Its population of 158 million is often considered to be a liability. However, it should be remembered that in $2013-2014$ the wage earners remittance inflow from Bangladeshis expatriate living abroad was US\$ 14,228.26 million (Source: Bangladesh Bank, 2015). As the development budget of the country was Taka 673.27 billion, during that period, the remittance inflow cannot be considered insignificant.

Nevertheless, it can be inferred that export of man-power has not reached full potential and holds vast opportunities for Bangladesh. A weakness Bangladesh exhibits in this respect is the lack of training and development. More than $65 \%$ Bangladeshis working abroad are unskilled or semi-skilled. As such, they earn minimum or below average wages (BMET, 2015). It can be assumed that remittance inflow to the country can be increased considerable by sending more skilled workers or professionals abroad.

Bangladeshi nurses have been working abroad for some time now. There is evidence to suggest that a considerable number of nurses went to the gulf countries in1985 -1986. More than 1000 nurses migrated from Bangladesh between 1991 and 2004 (Aminuzamman, 2007). However, at present the number of Bangladeshi nurses working abroad is negligible. To have an effect on the economy the migration should be on a larger scale. The opportunities that exist in the placement of Bangladeshi nurses in foreign countries may be explored.

\section{Objective And Methodology}

The broad objective of the paper is to identify the potentials that exist and the challenges that are faced by nursing professional from Bangladesh in gaining international market access. The roles of nurse training institutes, government, professional and private institutions were also assessed in this context.

The specific objectives of the paper and major sources of data are given below in tabular form:

Table 1: Specific objectives of the paper and major sources of data

\begin{tabular}{|l|l|}
\hline SPECIFIC OBJECTIVES & MAJOR SOURCES OF DATA \\
\hline $\begin{array}{l}\text { Analysis of the present and future demand and supply } \\
\text { situation in both domestic and global market }\end{array}$ & Secondary sources \\
\hline $\begin{array}{l}\text { Evaluating the quality of Bangladeshi nursing schools and } \\
\text { determining their capacity and growth potentials }\end{array}$ & $\begin{array}{l}\text { Site visit, interview of management at } 8 \text { nursing training } \\
\text { institutions, interviewing 20 nursing students and 42 nurses }\end{array}$ \\
\hline $\begin{array}{l}\text { Evaluating the product quality of Bangladeshi nurses as } \\
\text { compared to global standards }\end{array}$ & $\begin{array}{l}\text { Interview of 12 nurses who have worked abroad, interview of } \\
\text { officials of international recruiting agencies }\end{array}$ \\
\hline $\begin{array}{l}\text { Examining the policy and regulatory framework concerning } \\
\text { the international placement of Bangladeshi nursing } \\
\text { Professions }\end{array}$ & $\begin{array}{l}\text { Secondary sources, interview of officials from various } \\
\text { institutions and the Government of Bangladesh }\end{array}$ \\
\hline
\end{tabular}

A convenience sampling technique was used to select the interviewees. A questionnaire with a seven point Likert scale was used in the interview of the nurses. 
Michael Porter came up with the idea of Value Chain in 1985 and the concept of Global Value Chain (GVC) was developed a few years after that. GVC can be defined as 'a value chain that a divided among multiple firms and spread across wide swaths of geographic space' (Duke University, 2014). This report uses GVC analysis on the nursing sector of Bangladesh to determine what interventions are required to develop this market.

Businesses have different tools to measure the internal and external environment they operate in. These include:

1. SWOT Analysis - A useful tool that allows management to focus on their strengths, minimize weakness and threats, and grasp the opportunities available.

2. PESTLE Analysis - can be used to identify and analyze the external environment an organization operates in.

3. Porter's Five Forces Analysis - a model to determine an industries attractiveness

In a sense, the analytical tool Triple Triangle Framework is a combination of the three tools mentioned above. It contains three triangles superimposed on one another. The three arms of the inner triangle represent a firm's internal factors, these are:

- Capacity: managerial and technical knowledge \& skill

- Capital: financial resource, access to credit etc.

- Culture: entrepreneur's risk-taking attitude, aggressiveness, profit-orientation, etc.

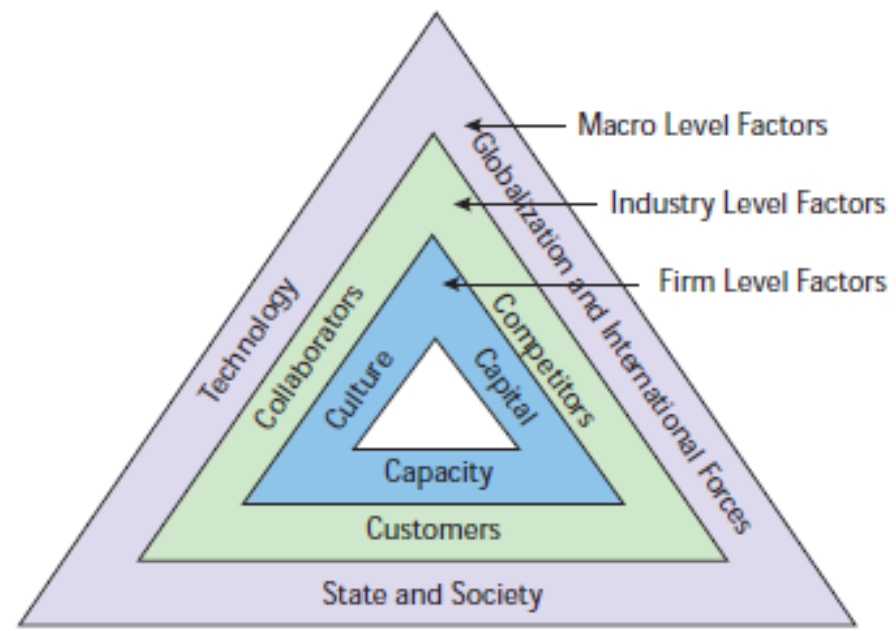

Source: Jahan 2008

Figure I: The Triple Triangle Framework

The middle triangle stands for market dynamics and comprise of the following:

- Customers: expectation, perception, awareness, etc.

- Competitors: attitude, nature, quantity, etc.

- Collaborators: suppliers, intermediaries, etc.

The outer triangle represents micro factors and include

- State and social forces: policymakers, regulators, facilitators, social institutions, etc.

○ Technology: the industry's growth trajectory and value chain

- Globalization and international forces: collaborator, global competitors, development agencies, etc. (Jahan, 2008)

The triple triangle framework (TTF) was used in this research to identify the major opportunities and obstacles to the placement of nurses in the world market.

\section{Scope Of The Research}

This research is specifically focused on the prospects and hurdles faced by Bangladeshi nurses in going abroad to pursue their career. Both male and female nurses (diploma and graduate) registered by the Bangladesh Nursing Council have been brought under the jurisdiction of the study. However, midwives, paramedics, family welfare visitors, medical technicians and patient care technologists (certified by the Bangladesh Technical Education Board) have been left out of its domain. 


\subsection{A Brief History of Nursing}

\section{Literature Survey}

The Royal College of Nursing (2003) defines nursing as "The use of clinical judgment in the provision of care to enable people to improve, maintain, or recover health, to cope with health problems, and to achieve the best possible quality of life, whatever their disease or disability, until death."

Healthcare practices were adopted by early civilizations. The concept of nurses (attendants) is found in Indian books on medicine from as early as $1400 \mathrm{BC}$ (BNENL, CMAI, 2008). Thereafter, nursing went through three images, the folk image (a "caring" person who uses common sense to help the sick individual), the religious image (focused on care for the sick, the poor, orphans, widows, the aged, slaves, and prisoners) and the servant image (hospital care was relegated to uncommon women, a group consisting of prisoners, prostitutes, and drunks) (Young et. al. 2003).

The idea of nursing went through a drastic change in the 17th century. By 1633 educated, intelligent, young women were being recruited to care for abandoned children as well as provide hospital care. Consequently, Florence Nightingale changed the whole concept of nursing during and after the Crimean War which started in 1854 and ended in 1856 (Ellis J.R. and Hartley C. L. 2012). Now-a-days nurses have moved away from just caring for the sick. These days Doctors of Nursing Practice (DNP) and PhD nurses are actively involved in developing health care policies. They are performing as hospital administrators and public safety personnel. Nurses are conducting and publishing scientific research and developing mobile medical applications (Tiffin C. 2012).

\subsection{Demand for Nurses in the Global Market}

Though it is an extremely important and essential profession in today's society, there is an acute shortage of nurses in the world. According to Tara Sonenshine (2014), a former U.S. Under Secretary of State for Public Diplomacy, by 2020 both the European Union and United States will face a shortage of one million nurses each.

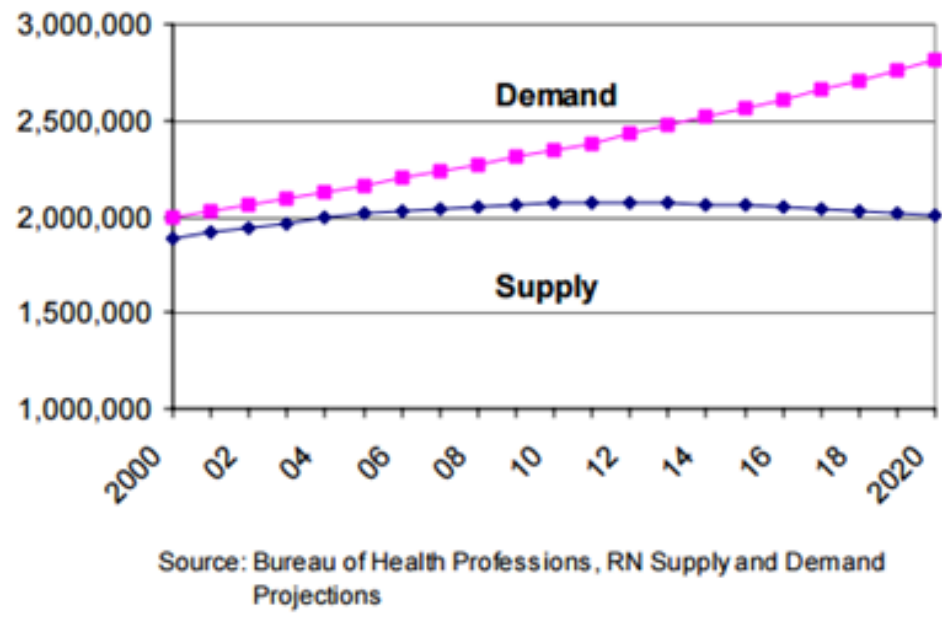

Figure II:

National Supply and Demand Projections for Registered Nurses: 2000 to 2020

In Europe, the number of elderly people, requiring nursing care is increasing though the supply of nurses is falling. The indifference of the younger generation to join this profession (other careers offer better prospects), inclination of nurses to leave the professions in search of better opportunities, retirement and migration (from Eastern to Western Europe) is creating an acute shortage of nurses (WHO Europe, 2015).

Across the Atlantic, Obamacare, the nick-name given to the Affordable Health Care Act will most likely boost the numbers of Americans who have access to healthcare facilities. Coupled with the fact that the baby Boomers are getting old and will need more care it is estimated (by the U.S. Bureau of Labor Statistics) that there will be job vacancy for one million nurses in the USA by 2020 (Sonenshine, T. 2014)

In the Gulf countries, nursing jobs are normally performed by people from other countries. According to the Ministry of Health's, Portal of the Kingdom of Saudi Arabia, there were 129,792 registered nurses in the country in $1431 \mathrm{H}$ (2009 -2010) out of whom 68.2\% were non-Saudi. In 2001-2002 around 80\% nurses working in the Gulf Co-operation Council (GCC) Region were expatriates (Mourshed et al, 2007). There is a permanent demand for foreign nurses in that region. 


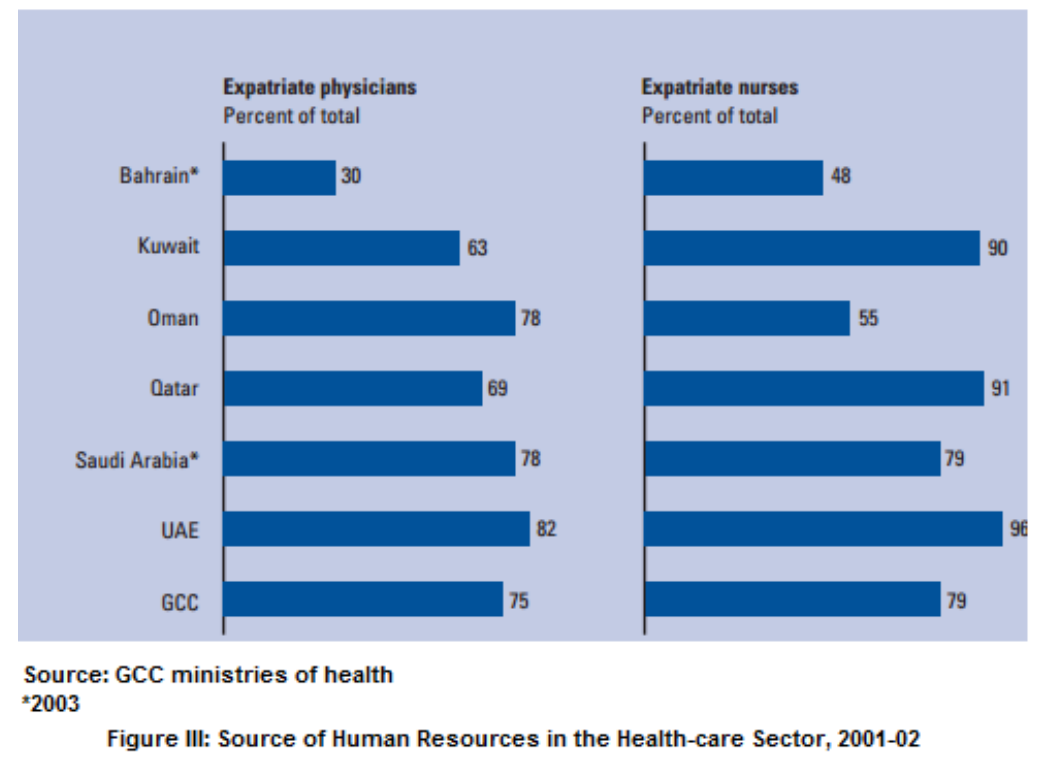

Similarly Canada, Australia and the Asian countries of Hong Kong, Japan, Malaysia, Singapore and Thailand are suffering or will suffer from nursing shortages soon (CIC News 2011), (Murphy 2012), (South China Morning Post, July 26, 2011), (Takeda and Satake, 2015), (Borneo Post Online, December1, 2011) and (Khalik, 2013).

\subsection{Supply of Nurses in the Global Market}

In the supply side, the Philippines, China and India are biggest suppliers of nurses in the world market. The Philippines is the largest exporter of nurses globally. Filipino nurses can be found in the United States, Saudi Arabia the United Kingdom, the Netherlands, Australia and Ireland (Lorezo et al., 2007). In 2013, there were 491 nursing schools in the country turning out approximately 100,000 nurses per year. Filipino nurses are well-trained, English-speaking (at least ten years of schooling where the medium is English ensured this) and willing to work abroad. They are willing to perform unwanted jobs at lower wages than local nurses, which encouraged hospitals in developed countries to fill up their nursing vacancies with Filipino nurses. Realizing the potential of exporting nurses, the Filipino Government promulgated laws and established policies that encourage the migration of nurses. A study in 2005 revealed that $85 \%$ of all Filipino nurses were working abroad (Philippines DATA BANK, 2013).

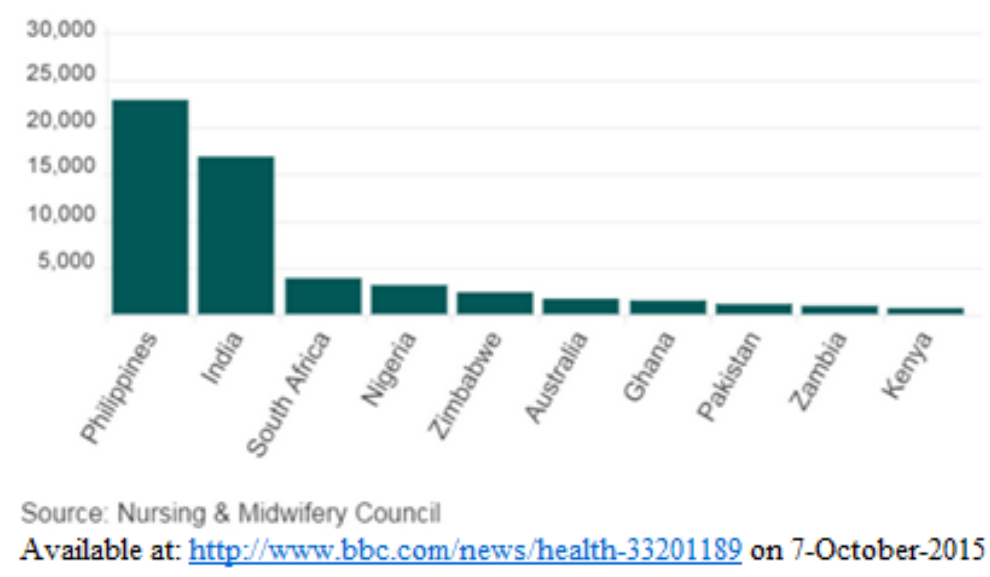

Figure IV: Foreign Nurses in the UK by Country of Origin, 2015

Between 2000 and 2006, 24242 Indian nurses appeared for the Commission on Graduates of Foreign Nursing Schools (CGFNS) exams being second only to Filipino nurses (Brush, 2008). India, which itself has a shortage of 2.4 million nurse (WHO International Bulletin, April 02, 2010) is becoming one of the leading exporters of nurses globally. 
Table II: Top 10 Countries of Origin of Nurses Taking the Commission of Graduates of Foreign Nursing Schools (CGFNS) Exam

\begin{tabular}{|c|c|c|}
\hline 1990-1995 & 1996-2000 & 2000-2006 \\
\hline 1. Philippines (52189) & 1. Philippines (27178) & 1. Philippines (51838) \\
\hline 2. Nigeria (1777) & 2. India (1981) & 2. India (24242) \\
\hline $\begin{array}{l}\text { 3. United Kingdom } \\
\text { (1675) }\end{array}$ & 3. Canada (1840) & 3. Nigeria (2425) \\
\hline 4. Saudi Arabia (1319) & 4. Nigeria (1742) & 4. China (1020) \\
\hline 5. India $(900)$ & 5. United Kingdom (478) & 5. UAE ${ }^{\mathrm{a}}(752)$ \\
\hline 6. UAE $(809)^{\mathrm{a}}$ & 6. Japan (268) & 6. Kenya (588) \\
\hline 7. Korea (681) & 7. Poland (253) & 7. Saudi Arabia (562) \\
\hline 8. Canada (581) & 8. China (244) & 8. Canada (561) \\
\hline 9. Ireland (550) & 9. Ghana (222) & 9. Kuwait (559) \\
\hline 10. Hong Kong (458) & 10. USSR (196) & 10. Taiwan (545) \\
\hline
\end{tabular}

Note. Information was created from Commission on Graduates of Foreign Nursing Schools data collated in 5-year periods. ${ }^{\mathrm{a} U A E}=$ United Arab Emirates.

Source: Brush, 2008

A research by Hawkes et al. (2009) reveled that India has a chance of losing up to $20 \%$ of her nursing force to other countries. However the good news is that most of these workers will return home after a few years spend abroad. India is now sending nursing professionals to UAE, KSA, Qatar, Oman, Kuwait, Bahrain, Malaysia, Libya, Jordan, Yemen, Sudan, Afghanistan, Indonesia, Syria, Lebanon, Thailand and Iraq (The Times of India, May 8, 2015). It may be mentioned here that India produces a large number of nurses every year. The state of Kerala alone has more than 100 nursing institutes and train thousands of graduates each year (Reuters Indian Ed., April 03, 2015).

China with about two million nurses has the second largest nursing workforce in the world (the USA being the first). Though well-trained the benefits and status bestowed upon Chinese nurses at home is not up to the mark. As such, they are inclined to work abroad (Xu, 2003). Germany has shown interest in engaging nurses from China (Lupieri, 2013).

\subsection{Nursing in Bangladesh}

Nursing education commenced in this region even before the partition of India-Pakistan, through the establishment of three Junior Nursing Schools under the Bengal Nursing Council (Directorate of Nursing Services website). At present (2015), according to the Bangladesh Nursing Council, there are 348 Nursing Institutes / Colleges (both government and private) in the country having a capacity of 16,235. They offer various courses ranging from the Community Based Skilled Birth Attendants course of six months duration to 4-years B. Sc in Nursing (Basic) courses. Specialized course on CCU, ICU, Cardiac Nursing and Rehabilitation Nursing are also available in the country (Bangladesh Nursing Council webpage).

Table III: Affiliated Nursing Institutes and Colleges

\begin{tabular}{|c|c|c|c|c|c|c|c|c|}
\hline \multirow{2}{*}{ SL } & \multirow{2}{*}{ Courses } & \multirow{2}{*}{ Duration } & \multicolumn{2}{|c|}{ Govt. } & \multicolumn{2}{|c|}{ Private } & \multicolumn{2}{|c|}{ Total } \\
\hline & & & $\mathrm{N} / \mathrm{NCC}$ & Seat & $\mathrm{NL/NC}$ & Seat & $\mathrm{NI} / \mathrm{NC}$ & Seat \\
\hline 1 & Diploma in Nursing Science \& Midwifery & 3 Years & 43 & 2580 & 91 & 4420 & 111 & 7000 \\
\hline 2 & Diploma in Midwifery & 3 Years & 38 & 975 & 13 & 410 & 51 & 1385 \\
\hline 3 & Diploma in Cardiac Nursing & 1 Year & 0 & 0 & 3 & 60 & 3 & 60 \\
\hline 4 & Diploma in Paediatric Nursing & 1 Year & 1 & 20 & 0 & 0 & 1 & 20 \\
\hline 5 & B. Se in Nursing (Basic) & 4 Years & 14 & 1035 & 30 & 1480 & 45 & 2515 \\
\hline 6 & B. Sc in Nursing/ Public Health Nursing (Post Basic) & 2 Years & 4 & 400 & 29 & 1125 & 34 & 1529 \\
\hline 7 & Family Welfare Visitors & 18 Months & 12 & 1000 & 0 & 0 & 12 & 1000 \\
\hline 8 & Junior Midwifery & 18 Months & 0 & 0 & 12 & 320 & 12 & 320 \\
\hline 9 & Community Paramedic & 2 Years & 4 & 100 & 23 & 1270 & 27 & 1370 \\
\hline 10 & Community Based Skilled Birth Attendants & 6 Months & 48 & 960 & 4 & 80 & 52 & 1040 \\
\hline \multicolumn{3}{|c|}{ Grand Total: } & 164 & 7060 & 205 & 9165 & 348 & 16235 \\
\hline
\end{tabular}

Source: Bangladesh Nursing Council 
Table IV

Bangladesh Nursing Council

Data Sheet of Total Registered

Up to: 31 October 2015

\begin{tabular}{|c|c|c|c|c|}
\hline SL & Name of Register Book in Bangladesh & Duration & \multicolumn{2}{|c|}{ Registered } \\
\hline 1. & Diploma in Nursing & 3 years & \multicolumn{2}{|c|}{20,171} \\
\hline 2. & Diploma in Midwifery & 1 year & 18,281 & \multirow{4}{*}{39,038} \\
\hline 3. & Diploma in Orthopaedic Nursing & 1 year & 1,685 & \\
\hline 4 & Diploma in Nursing Science \& Midwifery/Orthopedic & 4 years & 7,427 & \\
\hline 5 & Diploma in Nursing Science \& Midwifery & 3 year & 11,643 & \\
\hline \multirow{2}{*}{6} & B. Sc in Nursing/B. Sc in P.H. Nursing & 2 Years & \multirow{2}{*}{\multicolumn{2}{|c|}{3,457}} \\
\hline & B. Sc in Nursing (Basic) & 4 years & & \\
\hline
\end{tabular}

Source: Bangladesh Nursing Council

According to the Report of the Directorate of Nursing Services 2010 - 2012 there were 28,793 registered nurses in the country. Approximately $50 \%$ of them worked in government educational institutions and hospitals while the rest were engaged in private organizations and NGOs. The latter group also included approximately 1,100 nurses who were working abroad.

In 2007, there was a shortage of 187,000 nurses in Bangladesh. It was hoped that by increasing the number of nursing institutions and colleges the country would have 40,000 registered nurses by 2016 . That target has been achieved. At the same time, it must be mentioned that since 2012 the governments has been sending a number of nurses abroad every year to earn Masters or PhD Degrees in nursing. Also steps are underway to launch a Masters in Nursing course in Bangladesh. It is expected that these initiatives will eliminate the shortage of nursing teachers in the country.

\subsection{The Legal Frameworks}

In 1995 the General Agreement on Trade in Services (GATS) was created. The treaty allows member countries to decide which service sectors should enter into global trade. It provides the legal framework through which World Trade Organization (WTO) Members liberalize health-related and other services. Trade in health services includes the provision of nursing services (WHO, 2015).

The GATS agreement covers four modes of supply for the delivery of services in cross-border trade. Mode 4 is concerned with service delivered within the territory of the Member, with supplier present as a natural person. The term 'natural person' includes 'independent professionals,' and thus nurses (WTO, 2015). However, it must be said the response of the developed countries to mode 4 has not been satisfactory and they have not opened their doors as wide as expected, to professionals from developing countries (Kategekwa, 2014)

Also, the United Nations Convention on the Protection of the Rights of All Migrant Workers and Members of Their Families (ICRMW), the Convention on the Elimination of All Forms of Discrimination Against Women (CEDAW), United Nations (UN) Security Council Resolution 1325 on women, peace, and security and other international laws that protect the rights of migrant workers, and especially migrant women workers will be helpful in the placement of Bangladeshi nurses abroad (Barkat and Manzuma, 2014).

In Bangladesh, the principal law covering manpower export is the Overseas Employment \& Migrants Act of 2013. The act's main objective is to protect the rights of the workers going abroad. In addition to the act the Expatriates' Welfare and Overseas Employment Policy 2014 has a section on female workers which is helpful in the international placement of nurses (Website of MEWOE, 2015)

Different countries have different rules and regulations concerning migrating workers. For example the UK has implemented a law whereas non-European workers will have to leave the country if they are not earning at least $£ 35,000$ after six years. Besides nurses who were trained outside Europe can only apply for a work permit if they have

- $\quad$ been practicing as a nurse for at least one year or have practiced for at least 450 hours in the last 3 years 
- $\quad$ undertaken the Overseas Nurses Programme (ONP), which consists of 20 days of learning and covers topics like UK law, health and safety issues, record-keeping, drugs administration and Code of Conduct.

- $\quad$ taken the IELTS (International English Language Testing System)

- $\quad$ been sponsored by a hospital, private clinic or company (Heacock, 2011).

Similarly, to work in Australia one must be registered with a State Nursing Board. The requirements are rigorous (Nursing Careers Australia, 2015). The entry procedure to the US is also as stringent. These procedures discourage the entry of nurses into many developed countries.

\section{Global Value Chain Analysis For Export Of Nurses}

Michael Porter's value chain (1985) had five functions classified as primary activities. These are inbound logistics, operations, outbound logistics, marketing \& sales, and service. The global value chain for the international placement of Bangladeshi nurses can be adapted from it. The links in the value chain are inputs, operations, marketing and sales and markets.

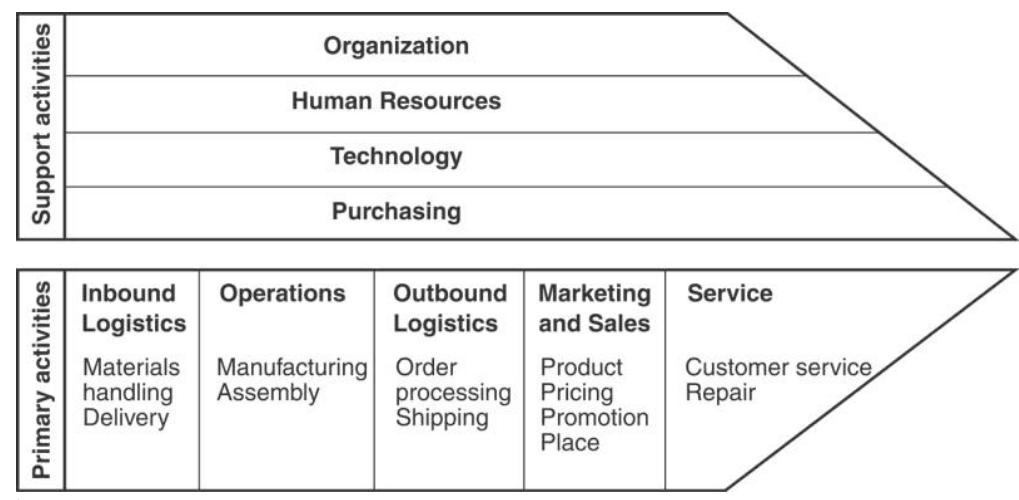

Source: Porter, 1985

Figure V (a): Michael Porter's Value Chain

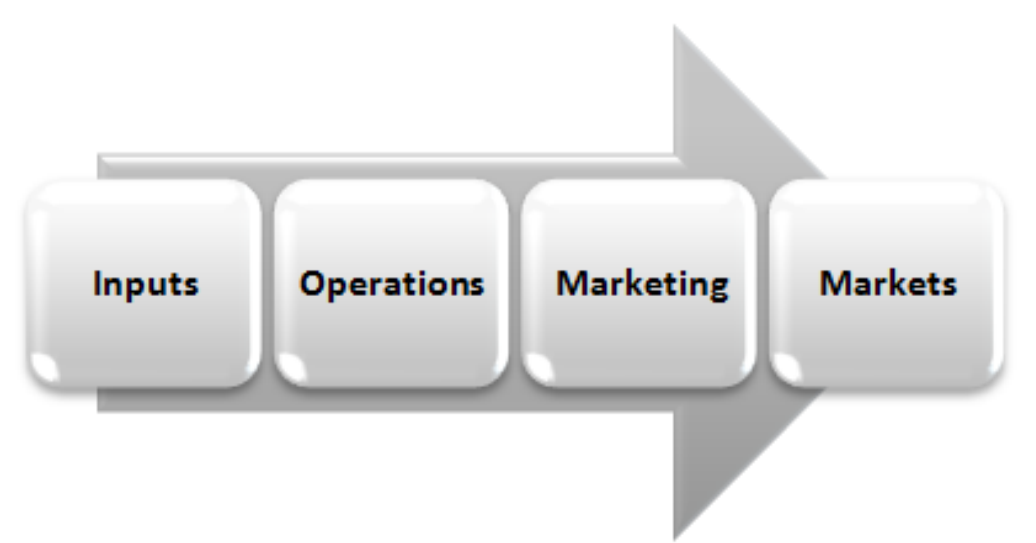

Fig. V (b): Value Chain for the International Placement of Bangladesh Nurses

\subsection{Inputs}

The people who constitute the nursing workforce are the main inputs in this value chain. Though the situation is changing rapidly, traditionally, people from economically challenged families joined the nursing profession. Even so, they had to overcome a strong resistance from society to accept nursing as an occupation. Nearly $80 \%$ of the nurses interviewed agree to some extent that society does not consider the profession to be honorable. Also they are mostly from rural areas and educated in schools of little or no repute. Their proficiency in English language is poor.

Students having below-average aptitude can get admitted into nurse training institutes in Bangladesh. The admission criteria to nursing schools are somewhat relaxed. For example, to apply for a degree in B.Sc. (Nursing) a candidate needs a CGPA of 5 (total) in SSC and HSC; whereas, to qualify for the Kha unit (Faculties of Arts, Social Sciences, the Department of Geography and Environment etc., University of Dhaka.) students must have a combined CGPA of 7.00 .

$60 \%$ of the nursing students interviewed think that the profession is very suitable for developing a career; $30 \%$ consider ease of obtaining employment as a plus point. However, the economic situation of newly 
passing out nurses sometimes throttles their drive. They are quite often satisfied with the jobs they land immediately on passing out as they can start supporting their families. Though they would like to work in foreign countries they lack the initiative required to search for employed abroad and they certainly lack the self confidence for foreign employment.

However, Bangladeshi nurses who have worked abroad are proud of their achievements and see no reason why their compatriots cannot be successful in the global market.

\subsection{Operations}

The operations part of the Global Value Chain in supplying nurses to the world market is mainly carried out by the nurse training institutions. Nurse training institutions in Bangladesh can be classified in a number of manners. For example, there are government and private training institution; there are captive institutions that supply nurses to parent hospitals, profit earning institutions and social businesses. A number of institutions are attached to public or private universities like the College of Nursing - University of Dhaka, College of Nursing - IUBAT, etc. Some training schools offer nursing B.Sc. And MPH degrees while others offer Diplomas of various durations and specializations.

Sadly, the views of the nurses interviewed were not flattering to nursing education in Bangladesh. More than $75 \%$ of the nurses interviewed agreed that Bangladeshi nursing schools, their faculties, facilities, teaching methods and foreign (English) language development practices were not satisfactory. $60 \%$ of the nursing students interviewed identified lack of facilities while 50\% mentioned shortage of qualified teachers as weaknesses of nursing education in the country.

The curriculum for nursing education in Bangladesh has been prepared by the Bangladesh Nursing Council with support from the Ministry of Health and Family Welfare, World Health Organization (WHO) and the Directorate of Nursing Services. It is considered to be of global standard by the experts interviewed.

The facilities available in the nurse training schools vary from institute to institute. There are institutions that offer state of the art facilities in classrooms, libraries, laboratories, IT and even residential hostels; on the other hand some operate with make-shift arrangements.

\section{The Grameen Caledonian College of Nursing - An example to follow}

With the aim of developing international level nursing and midwifery standards in Bangladesh, an agreement was reached, in 2009, between The Grameen Trust and Glasgow Caledonian University (GCU), Scotland to establish a high quality college for nurses and midwives in Dhaka. Similar projects have been successfully completed by GCU Professors and professional experts in other developing nations, such as Kosovo and Tajikistan

The college has been set up with joint funding from Nike Foundation of USA and Glasgow Caledonian University, Scotland, U.K. The Grameen Healthcare Trust (GHT) supports the funding arrangements of the College while the Grameen Health Care Services Ltd. (GHS), oversees the establishment of the college as a social business company of the Grameen Family.

The Nursing College is compatible with international standards and meets all the requirements of the Bangladesh Nursing Council (BNC) and other Government agencies. Students follow the national curriculum set by the BNC in English. Considerable emphasis is given on developing the English Language and IT skills of the students. To achieve this GCCN has two full time English Language teachers on board.

For its Diploma Program, students are selected only from Grameen Bank Borrower families from all over Bangladesh. They attend class in well equipped rooms and enjoy modern library and laboratory facilities. Students are provided with hostel accommodation. They take their meals in the Grameen Training Hostel.

Most significantly, GCCN students can avail of student loans at easy terms and are assured of employment on the successful completion of their course.

The first batch of students who started attending classes for a diploma in Nursing Science and Midwifery passed out with flying colours in March 2013.

The College has started offering BSc Nursing programmes and plans to introduce a Nurse Teacher training programme at Masters Level. A further 10 colleges of nursing are planned across the country.

At present, there is a shortage of dedicated nursing teachers in Bangladesh. While reputed training schools have the first choice in selecting proficient faculties, smaller training schools often have to rely on parttime teachers. Also, doctors and nurses who have Masters Degree in Public Health (MPH) constitute a formidable percentage of nursing teachers in the country. However, this problem will most likely be overcome soon. Since 2012, the Bangladesh Government has been sending a number of nurses abroad every year to obtain Masters and $\mathrm{PhD}$ degrees in nursing. Also, the country is ready to launch a Master in nursing program soon. It is expected that the country will have a sufficient number of nursing teachers in the days to come. 


\subsection{Marketing}

Without any doubt, marketing is the weakest link the value chain for exporting Bangladeshi nurses. All the experts interviewed during this research have identified the lack of marketing as one of the major barriers to the international placement of Bangladeshi Nurses.

Bangladesh is not at all proactive in marketing nurses; sometimes it seems that it is not also reactive. At times, teams have come from abroad to explore the possibility of employing nurses from Bangladesh but quite often they had to return empty handed due to a lack of support from their Bangladeshi counterparts.

\subsection{Markets}

The shortage of nurses in the world market is very much evident. Developed countries are filling up the gap with nurses from other countries. As such, there are ample opportunities for Bangladeshi nurses to work abroad. However, gaining access to the market is difficult for a number of reasons; the most identifiable among which are indifference by the government and language capability of our professionals. Nurses interested to go abroad do not have information on position openings and do not know how to apply for foreign jobs.

\section{Applying The Triple Triangle Analysis}

The triple triangle analysis concentrates on factors affecting three levels of business environment - a firm's internal factors, industry-level factors (which influence all the firms across the industry) and macro-level factors. The analysis was deployed on the migration of Bangladeshi nurses abroad.

\subsection{Firm's Internal Factors}

The culture of nursing institutes in the country varies with their objectives. Government nursing schools have been set up in Bangladesh to fulfill people's mandate, while hospitals have nurse training institutions to satisfy internal needs. Private nursing colleges are, in most cases, profit oriented though there are a few social businesses. Nursing schools associated with private universities have their reputation to maintain as well as recover costs at least.

Nursing schools do not vary only in terms of culture, capacity and courses offered but also in terms of the quality of the teaching staff and infrastructure. While branded institutions like the Grameen Caledonian College of Nursing, Square Nursing College and the Dhaka Nursing College have sufficient good teachers many unbranded schools are suffering from a scarcity of trainers and are dependent on part-time faculties. Similarly, while some nursing schools have full-fledged libraries, laboratories, computer center and even hostels for students a large number of schools offer students basic classroom facilities in rented premises.

In Bangladesh, investing in a nurse training institute is not a very lucrative proposition. Top level schools like the Grameen Caledonian College of Nursing and the IBN SINA Nursing Institute have not reached breakeven point yet though both have started operations in 2010. In Bangladesh nursing students do not come from affluent families. As such, they are usually not in a position to pay high fees. However, they often require auxiliary services like hostel facilities, student loans, etc. Some nursing schools provide this facility, which requires additional capital. However the return on investment is very slow.

\subsection{Industry Level Factors}

Customers for Bangladeshi nurses exist in both the home and foreign markets. In fact, some experts doubt whether Bangladesh should be exporting nurses at all before meeting the local demand. Even when compared to our neighboring countries like India and Pakistan the population to nurse ratio in Bangladesh is alarming. The easy entry into the local job market combined with pressure from family and society not to seek employment aboard is making the 'deshi' (local) nurses lose their initiative to enter foreign markets.

Table V: Nursing and Midwifery Personnel per 1000 population.

\begin{tabular}{|l|l|l|}
\hline Country & No. per 1000 & Year \\
\hline Bangladesh & 0.218 & 2011 \\
\hline Sri Lanka & 5.665 & 2013 \\
\hline Pakistan & 0.573 & 2010 \\
\hline India & 1.711 & 2011 \\
\hline Saudi Arabia & 4.860 & 2012 \\
\hline UK & 8.800 & 2013 \\
\hline USA & 9.810 & 2005 \\
\hline Japan & 10.864 & 2010 \\
\hline
\end{tabular}

Sources: Global Health Observatory Data Repository, WHO

There is demand for nurses in both local and global markets but competition is more acute in the global market. Bangladesh has fallen far behind countries like the Philippines, India and China in the global market for nurses. It has to start from zero and fight its way up against very strong competitive forces. However, 
Bangladeshi workers are well known the world over and this might be beneficial for them. Another advantage for Bangladeshis is that the reimbursement package demanded by them is very competitive. Even so, the salary earned by a nurse working abroad would usually be a much higher than what he/she could earn in the country.

Another difference between the home and foreign market is that though diploma nurses are acceptable in Bangladesh, they are not recognized by some countries of the world. In the UK to register with the Nursing and Midwifery Council (NMC) one must have a degree in pre-registration nursing. The nursing diploma has been invalidated there. In Australia, diploma nurses may work as Enrolled (second-level) Nurse. To work as a Registered (first-level) Nurse one must have a bachelor degree or higher qualification. In the USA, though acceptable, the number of graduate nurses far exceeds the number of diploma nurses (AACN, 2015).

In Bangladesh, to be a nurse one often has to struggle against society and even family. However, it would seem as if local nurses are unable to fight for their own rights. Due to this the statuses of nurses have not improved very much. Also, one of the major barriers to the migration of nurses is the lack of information and acumen. Local nurses do not know what positions are available for them abroad, how to apply for them or how to prepare for competition against nurses from other countries. Nearly $80 \%$ of the nurses interviewed considered unavailability of trained recruiters to be a major barrier to their seeking employment in foreign countries.

The support of collaborators like the Bangladesh Nursing Council (BNC) is extremely important to nurses wishing to work abroad. The Bangladesh Nursing Council (BNC) is the administrative body that manages all functions relating to nursing. These include (i) provision and renewal of nursing licenses, (ii) regulation of nursing education and practices, (iii) approving nurse training institutions, (iv) setting questions and conducting exams; tabulating and publishing results and (v) maintaining liaison with national and international bodies

Other bodies like the Bureau of Manpower, Employment and Training (BMET), Bangladesh Overseas Employment and Services Ltd. (BOESL) and other international recruiters also have important roles to play here. Incidentally, it may be mentioned that BOESL the only the "State owned" manpower exporting company in Bangladesh has not been able to send a nurse abroad in thirty decades.

\subsection{Macro Level Factors}

In Bangladesh society has always considered the nursing profession to be 'taboo' and the concept of women (the majority of nurses are women) going abroad for work has been frowned upon. Thus society has resisted the export of nurses and required support has not come from the state.

The Director of Nursing Services is the apex organization for the administration of nursing services and education in Bangladesh. Its responsibilities include (i) Nursing policy development, (ii) Strategic and operational planning of nursing services and education, (iii) Management of public sector Nursing Institutes and Nursing Colleges, (iv) Planning and management of development projects and (v) Coordination with BNC. DNS has failed to live up to the expectations of the nursing community

Mode 4 of GATS has cleared the path for the migration of nurses from one country of the world to another. There are also several international laws protecting the rights of migrant (women) workers. However it is mainly the high demand and short supply situation which will ensure that globalization and international forces support the migration of nurses.

There are technological changes in the global nursing arena but Bangladeshi nurses have the capability to cope with these changes. On the other hand, it might be said that cultural, political and legal issues have more effect on Bangladeshi nurses. For example while Bangladeshi nurses are adaptable and can work in all countries of the world, they are more comfortable working in the Middle East due to the matching of cultures. The unofficial ban on import of workers from Bangladesh to Saudi Arabia and other countries imposed in 2008 has played havoc with the placement of nurse in the target markets. The ban has recently been lifted.

\section{Interventions Required}

To boost the access of Bangladeshi nurses in the global market the barriers pointed out in this report have to be removed and the opportunities exploited. The following interventions may be helpful in achieving this goal.

- Nursing as a profession in Bangladesh is still not considered 'prestigious' by society and even family. The inclusion of B.Sc. courses especially under public and private universities is gradually bringing a change to this mindset. The range of young people wanting to accept nursing as a profession should be expanded by properly promoting the industry.

- As many student nurses come from economically challenged families they require financial assistance to continue their studies. 'Study now pay later' plans are available in the nursing industry as some nurse training schools provide student loans. This should be expanded with involvement of the government and financial institutions.

- The entry requirements to nursing schools may be strengthened to raise the standards of nurses in the country 
- Private Universities and hospitals should be encouraged to set up more nurse training institutions. However, there should be strict monitoring of the teaching quality and faculty as well as the facilities.

- The capacity of public sector nurse training institutions should also be increased.

- Greater emphasis should be provided on the development of language and behavioral skills of nurses. In our nursing schools, the mode of instruction is English; nursing institutions should be compelled to have full-time teacher to teach English

- Nursing students and even nurses in Bangladesh have very little idea about examinations for licensing of nurses required by many countries. Nursing institutes should conduct optional courses on how to succeed in these examinations.

- Bangladeshi nursing institutes should enter into collaboration with hospitals and other health facilities to enable their students to receive on-the-job training

- Every year Bangladesh produces more diploma nurses than graduate nurses. Though this is suitable in the Bangladeshi context, the number of diploma nurses is declining the world over. Bangladeshi Nurse Training Schools should start giving more emphasis on producing graduate nurses.

- Specialised nurses are in high demand the world over. Nursing schools in Bangladesh may concentrate on offering more specialised nursing courses.

- Local nursing schools may enter into collaboration with reputed, foreign nursing institutes to make their degrees more acceptable in the global market

- The M.Sc. in nursing course should be launched, in the country, at the earliest and the capacity developed to send more nurses abroad in M.Sc. and Ph.D. programs. Development of a strong pool of teachers is essential for the growth of the industry

- The promotion of Bangladesh as a supplier of nurses to the world market is very important. The government has an extremely important role to play here and so does the private sector (recruitment agencies).

- The Bangladesh government may enter into bilateral agreements with countries which use migratory nurses, for preferential treatment in supplying nurses and at the same time to ensure that Bangladeshi nurses are not exploited, financially, sexually or otherwise..

\section{Conclusion}

The following conclusions may be arrived at the end of this study:

- There is a considerable demand for nurses in both domestic and global markets

- Bangladesh will reach its target on number of registered nurses for 2016. Its present capacity is approximately 7,000 diploma nurses and 4,000 B.Sc. nurses. However, by promoting the profession, increasing the pool of teachers and other interventions the capacity of nursing training institutions in Bangladesh can be enhanced

- $\quad$ The product qualities of Bangladeshi nursing schools vary. However, some schools are capable producing world class nurses

- There are no policy and regulatory barriers against international placement of Bangladeshi nursing professionals.

- The main challenges to the international placement of nurses are government indifference, language and social issues, lack of acumen by our nurses about going abroad. The opportunities include huge demand in the global market and competitive compensation packages acceptable to our nurses.

Though it is debatable whether Bangladesh should export nurses at present (considering the extreme shortage within the country) there can be no doubt that the country has the potential to supply nurses to the world. Through proper and timely interventions of the stakeholders, it should be possible for Bangladesh to meet its own needs and supply nurses to the world in 5 / 10 years. To achieve this Bangladesh can adapt the highly successful model developed by the Philippines.

\section{References}

[1]. American Association of Colleges of Nursing (AACN), 2015, Nursing Fact Sheet, Washington, DC Available at: http://www.aacn.nche.edu/media-relations/fact-sheets/nursing-fact-sheet as on 07-September-2015

[2]. Aminuzamman, S.M., 2007, Migration of Skilled Nurses from Bangladesh: An Exploratory Study, Development Research Centre on Migration, Globalisation and Poverty, University of Sussex, UK

[3]. Bangladesh Bank, 2015, Economic Data, Wage Earners' Remittance Inflow, Available at: https://www.bb.org.bd/econdata/wageremitance.php\# as on 07-September-2015

[4]. Barkat, A. and Manzuma, A, 2014, Gender and migration from Bangladesh : mainstreaming migration into the national development plans from a gender perspective International Labour Organization, ILO Country Office for Bangladesh. - Dhaka

[5]. BMET (Bureau of Manpower, Employment and Training) Website, Available at: http://www.bmet.gov.bd/BMET/stattisticalDataAction as on 07-October-2015 
[6]. Board of Nursing Education, Nurses League (BNENL), Christian Medical Association of India (CMAI), South India Branch, 2008, A New Textbook for Nurses in India, Volume 1. $5^{\text {th }}$ Ed., B.I. Publications Pvt. Ltd. New Delhi, India Available at: https://books.google.com.bd/books?id=MwSvARy_ducC\&pg=PA3\&dq=history+of+nursing+in+india\&source=gbs_toc_r\&cad=3\# $\mathrm{v}=$ onepage \&q=history $\% 20 \mathrm{of} \% 20$ nursing $\% 20$ in $\% 20$ india\&f=false on 02 -October-2015

[7]. Borneo Post Online December 1, 2011, Staff shortage makes nursing jobs harder, available at: http://www.theborneopost.com/2011/12/01/staff-shortage-makes-nursing-jobs-harder/ as on 07-October-2015

[8]. Brush, B.L., 2008, Global Nurse Migration Today, Journal of Nursing Scholarship, First Quarter 2008, pp 20 - 25

[9]. Bureau of Health Professions, 2002, Projected Supply, Demand, and Shortages of Registered Nurses: 2000-2020, Health Resources and Services Administration, U.S. Department of Health and Human Services available at: http://www.ahcancal.org/research_data/staffing/documents/registered_nurse_supply_demand.pdf on 07-October-2015

[10]. CIC News 2011 Foreign-trained Nurses are Just What the Doctor Ordered available at: http://www.cicnews.com/2011/01/foreigntrained-nurses-doctor-ordered-01825.html on 12-May-2015

[11]. Duke University, 2014, Global Value Chains Initiative, Center on Globalization, Governance \& Competitiveness (CGGC) available at: https://globalvaluechains.org/concept-tools on 12-May-2015

[12]. Ellis J.R. and Hartley C. L. 2012. Nursing in Todays World : Trends, Issues \& Management, $10^{\text {th }}$ edition, Wolters Kluwer Health | Lippincott Williams \& Wilkins, Philadelphia,, USA

[13]. Hawkes, M., Kolenko, M., Shockness, M. and Diwaker, K. 2009, Nursing brain drain from India, Human Resources for $\begin{array}{llllll}\text { Health. 2009; 7: } & \text { 5. Published online } 2009 & \text { February } & \text { 2. doi: } 10.1186 / 1478-4491-7-5 & \text { available at: }\end{array}$ http://www.ncbi.nlm.nih.gov/pmc/articles/PMC2642753/ as on 07-October-2015

[14]. Heacock, 2011, Nurse in the UK: The Requirements, NurseTogether LLC., available at: https://www.healthxchange.com.sg/News/Pages/singapore-faces-nurse-shortfall-years.aspx as on 07-October-2015

[15]. Jahan, S.M, 2008, Market Development \& SME Competitiveness: Does government policy Address SME Challenges? Journal of Business Administration Vol. 34, No. 1 \& 2, January \& April 2008, pp 53 -67

[16]. Kategekwa, J. 2014, Opening Markets for Foreign Skills: How Can the WTO Help?: Lessons from the EU and Uganda's Regional Services Deals, Springer Science+Business Media Berlin, Heidelberg, New York

[17]. Khalik, S., February 15, 2013 Singapore Faces Nurse Shortfall for Years to Come Health.Xchange.com.sg available at: https://www.healthxchange.com.sg/News/Pages/singapore-faces-nurse-shortfall-years.aspx as on 07-October-2015

[18]. Lorenzo, F.M.E., Galvez-Tan, J., Icamina, K. and Javier, L., 2007, Nurse Migration from a Source Country Perspective: Philippine Country Case Study, Health Services Research. 42(3 Pt 2): 1406-1418. available at: http://www.ncbi.nlm.nih.gov/pmc/articles/PMC1955369/ as on 07-October-2015

[19]. Lupieri, S Where have Europe's nurses gone? CNN May 21, 2013, Cable News Network. Turner Broadcasting System, Inc. Available at: http://edition.cnn.com/2013/05/21/health/europe-nursing-shortage/index.html as on 07-October-2015

[20]. Mourshed, M., Hediger, V. and Lambert, T. 2007 Gulf Cooperation Council Health Care: Challenges and Opportunities, Arab World Competitiveness Report 2007, Chapter 2.1, World Economic Forum Geneva, Switzerland

[21]. Murphy, K., March 28, 2012, Nursing shortage crisis looming, The Sydney Morning Herald, Fairfax Media. Available at: http://www.smh.com.au/federal-politics/political-news/nursing-shortage-crisis-looming-20120327-1vwl6.html\#ixzz3o0e26hYs as on 02 -October-2015

[22]. Nursing Careers Australia, 2015, Australian Registration Requirements, Available at: http://www.nursingcareersaustralia.com/nursing-careers/how-do-i-become-a-nurse-in-australia/australian-registration-requirements/ as on 07 -October-2015

[23]. Nursing and Midwifery Data Bank - The Philippines, 2013, WHO Western Pacific Region, available at: http://www.wpro.who.int/hrh/about/nursing_midwifery/db_philippines_2013.pdf as on 07-October-2015

[24]. Porter, M. E. 1985, Competitive Advantage: Creating and Sustaining Superior Performance. New York.: Simon and Schuster.

[25]. Reuters Indian Ed., April 03, 2015, To stay or go? Indian nurses abroad weigh debts against danger, available at: http://in.reuters.com/article/2015/04/02/yemen-india-nurses-idINKBNOMT2M620150402 as on 07-October-2015

[26]. Royal College of Nursing, 25 February 2015, Nursing shortage is very real, RCN tells Migration Advisory Committee 20 Cavendish Square, London W1G 0RN, UK. Available at https://www.rcn.org.uk/newsevents/news/article/uk/nursing-shortage-isvery-real-rcn-tells-migration-advisory-committee as on 07-October-2015

[27]. Sonenshine, T. 2014 Nurses Urgently Needed: Another Critical Global Shortage - Why Nurses Need us to Care, The Globalist . Washington, D.C. available at: http://www.theglobalist.com/nurses-urgently-needed-another-critical-global-shortage/ on 12-May2015

[28]. South China Morning Post (July 26, 2011) Overseas nurses may ease shortage, South China Morning Post Publishers Limited, Morning Post Centre, 22 Dai Fat Street, Tai Po Industrial Estate, Tai Po, New Territories, Hong Kong. Available at: http://www.scmp.com/article/974482/overseas-nurses-may-ease-shortage as on 07-October-2015

[29]. Takeda, T. and Satake, M. (April 7, 2015) Aging Asia Scrambling for Nursing Workforce, Nikkei Asian Review, Nikkei Inc, Available at: http://asia.nikkei.com/Business/Trends/Aging-Asia-scrambling-for-nursing-workforce as on 07-October-2015

[30]. The Times of India May 8, 2015, Overseas nursing recruitment now free, available at: http://timesofindia.indiatimes.com/city/kochi/Overseas-nursing-recruitment-now-free/articleshow/47194878.cms as as on 07October-2015

[31]. Tiffin, C. 2012 Beyond the Bedside: The Changing Role of Today's Nurses, Huffpost Good News, TheHuffingtonPost.com, Inc. available at http://www.huffingtonpost.com/charles-tiffin-phd/nursing-school_b_1384285.html on 12-May-2015

[32]. Website of Bangladesh Nursing Council: http://www.bnmc.gov.bd/index.html

[33]. Website of the Directorate of Nursing services: http://dns.gov.bd/

[34]. Website of the Ministry of Expatriates' Welfare and Overseas Employment (MEWOE), Government of the People's Republic of Bangladesh, Available at: http://probashi.gov.bd/ as on 07-October 2015

[35]. WHO International Bulletin, April 02, 2010, Wanted: 2.4 million nurses, and that's just in India, Available at: http://www.who.int/bulletin/volumes/88/5/10-020510/en/ as on 07-October-2015

[36]. WHO Regional Office for Europe 2015 Nursing and midwifery - Data and Statistics - Shortage of Nurses and Midwives available at http://www.euro. who.int/en/health-topics/Health-systems/nursing-and-midwifery/data-and-statistcs on 12-May-2015

[37]. WHO Trade, Foreign Policy, Diplomacy and Health, (2015), General Agreement on Trade in Services (GATS) available at $h$ http://www.who.int/trade/glossary/story033/en/ as on 07-October-2015

[38]. WTO Services: Sector by Sector, (2015), Movement of Natural Persons Available at: https://www.wto.org/english/tratop_e/serv_e/mouvement_persons_e/mouvement_persons_e.htm as on 07-October-2015 
[39]. Xu, Y., 2003, Are Chinese Nurses a Viable Source to Relieve the US Nursing Shortage?, Medscape, WebMD Health Professional Network Available at: http://www.medscape.com/viewarticle/465919_4 as on 07-October-2015

[40]. Young, A., Van Niekerk, C. F. and Mogotlane, S. (Editors), 2003, Juta's Manual of Nursing, Volume 1, Juta and Company Ltd, South Africa

Survey on 42 nurses:

\section{Appendix \\ Survey Results}
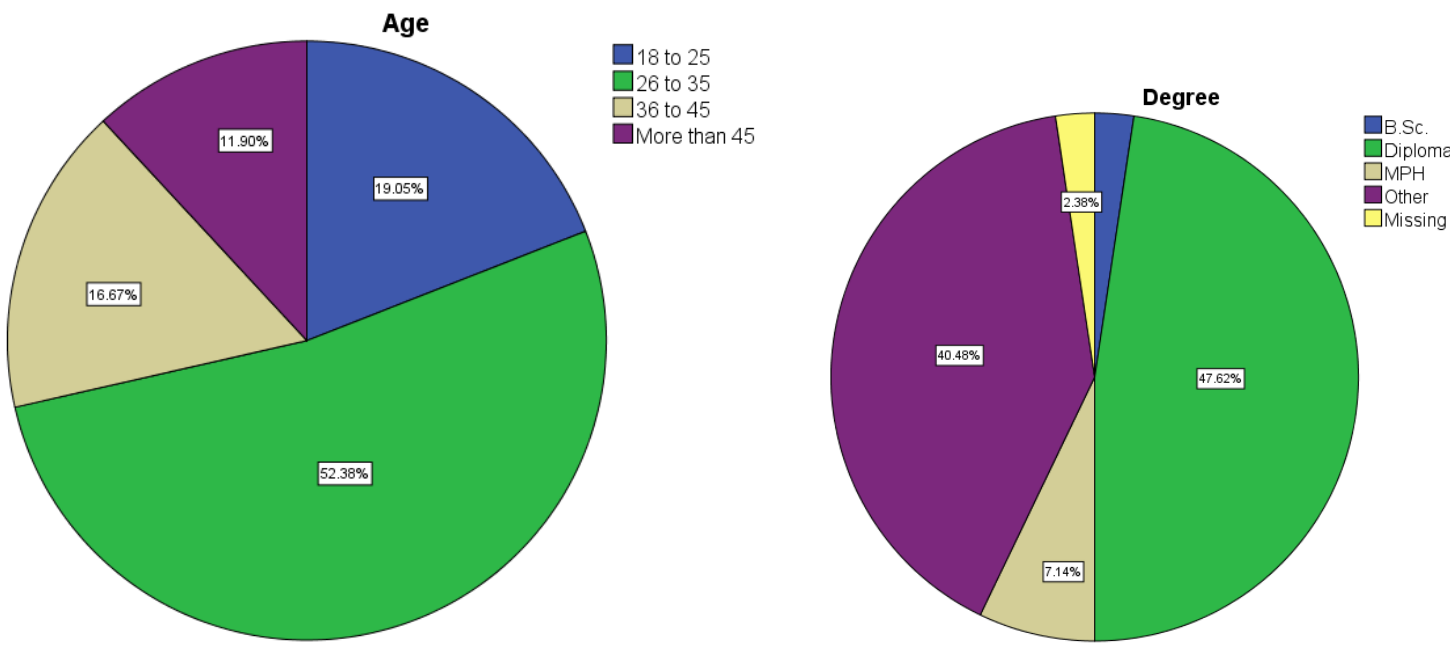

The nursing profession is not considered to be honorable by society in Bangladesh

\begin{tabular}{|ll|r|r|} 
& Frequency & Percentage \\
\hline Valid & Strongly disagree & 4 & 9.5 \\
& Disagree & 1 & 2.4 \\
Disagree somewhat & 4 & 9.5 \\
Agree somewhat & 17 & 40.5 \\
Agree & 6 & 14.3 \\
Strongly agree & 10 & 23.8 \\
Total & 42 & 100.0 \\
\hline
\end{tabular}

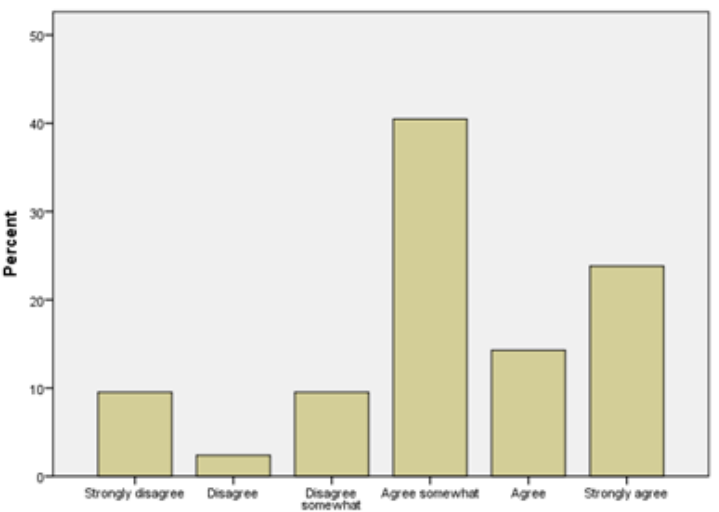

The nursing profession is not considered to be honorable by member of the family.

\begin{tabular}{|ll|r|r|}
\hline & Frequency & Percent \\
\hline Valid & Strongly disagree & 4 & 9.5 \\
& Disagree & 6 & 14.3 \\
& Disagree somewhat & 10 & 23.8 \\
Undecided & 1 & 2.4 \\
Agree somewhat & 10 & 23.8 \\
Agree & 10 & 23.8 \\
Strongly agree & 1 & 2.4 \\
Total & 42 & 100.0 \\
\hline
\end{tabular}

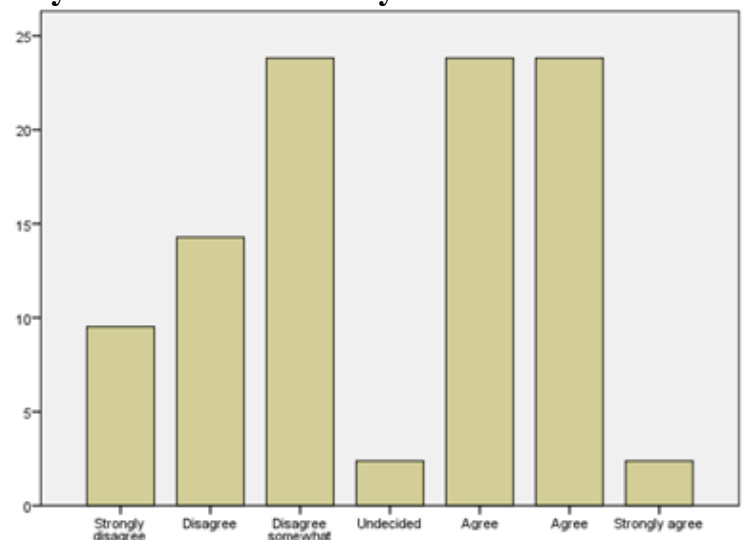


There is a lack of good nurses training institution in Bangladesh

\begin{tabular}{|ll|r|r|}
\hline & Frequency & Percent \\
\hline Valid & Strongly disagree & 1 & 2.4 \\
& Disagree & 8 & 19.0 \\
& Disagree somewhat & 1 & 2.4 \\
Agree somewhat & 3 & 7.1 \\
Agree & 22 & 52.4 \\
Strongly agree & 7 & 16.7 \\
Total & 42 & 100.0 \\
\hline
\end{tabular}

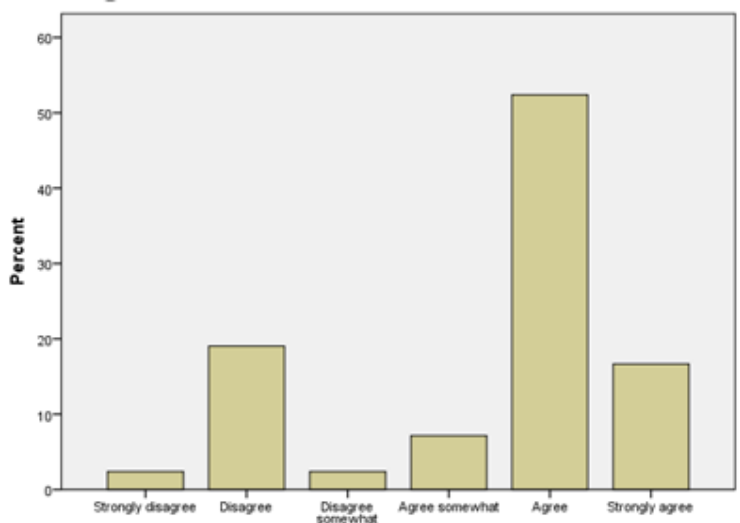

The faculty of nursing schools are not of international standard

\begin{tabular}{|ll|r|r|}
\hline & Frequency & Percent \\
\hline Valid & Strongly disagree & 2 & 4.8 \\
& Disagree & 4 & 9.5 \\
Disagree somewhat & 1 & 2.4 \\
Agree somewhat & 11 & 26.2 \\
Agree & 11 & 26.2 \\
Strongly agree & 13 & 31.0 \\
Total & 42 & 100.0 \\
\hline
\end{tabular}

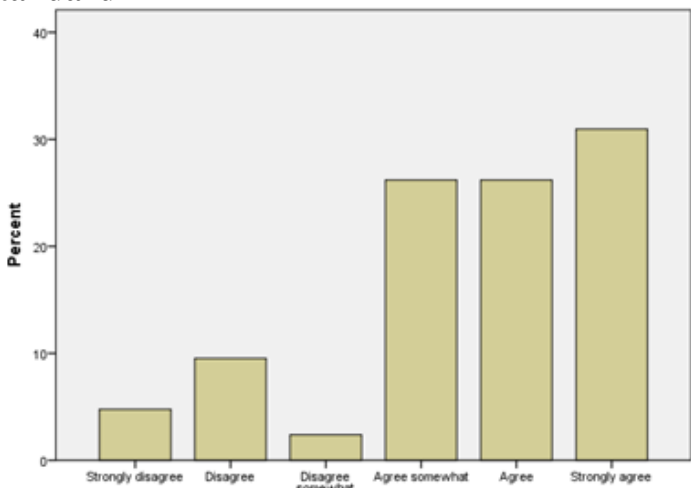

The teaching methods of our nursing schools are not suitable for placement abroad

\begin{tabular}{|ll|r|r|}
\hline & Frequency & Percent \\
\hline Valid & Strongly disagree & 5 & 11.9 \\
& Disagree & 1 & 2.4 \\
& Disagree somewhat & 2 & 4.8 \\
Undecided & 2 & 4.8 \\
Agree somewhat & 16 & 38.1 \\
Agree & 13 & 31.0 \\
Strongly agree & 3 & 7.1 \\
Total & 42 & 100.0 \\
\hline
\end{tabular}

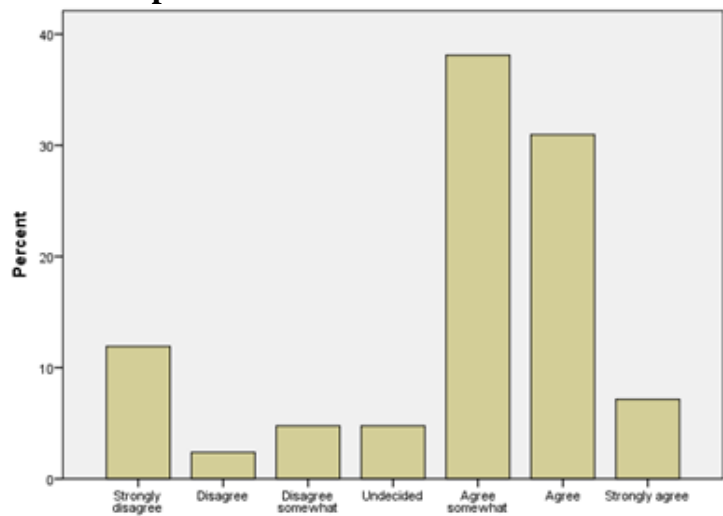

The Facilities at the nursing schools are not of international standard

\begin{tabular}{|ll|r|r|}
\hline & Frequency & Percent \\
\hline Valid & Strongly disagree & 4 & 9.5 \\
& Disagree & 3 & 7.1 \\
Disagree somewhat & 1 & 2.4 \\
Undecided & 1 & 2.4 \\
Agree somewhat & 13 & 31.0 \\
Agree & 13 & 31.0 \\
Strongly disagree & 7 & 16.7 \\
Total & 42 & 100.0 \\
\hline
\end{tabular}

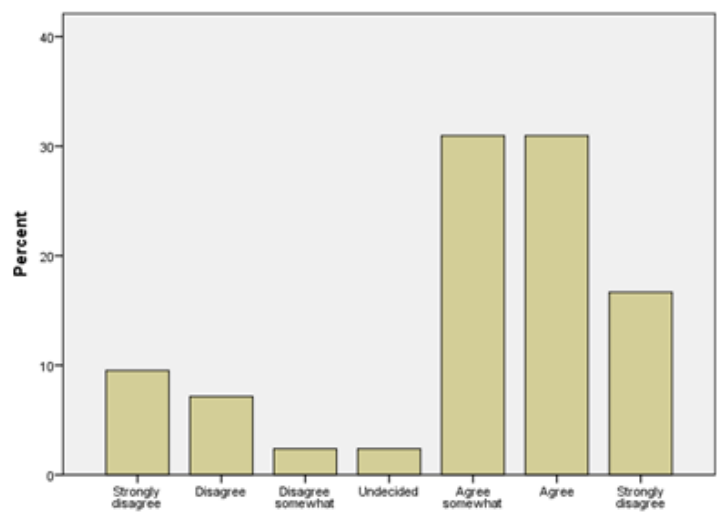


The practical (on the job) training that $I$ am receiving is not up to standard

\begin{tabular}{|ll|r|r|}
\hline & Frequency & Percent \\
\hline Valid & Strongly disagree & 7 & 16.7 \\
& Disagree & 8 & 19.0 \\
& Disagree somewhat & 10 & 23.8 \\
Agree somewhat & 11 & 26.2 \\
Agree & 3 & 7.1 \\
Strongly agree & 3 & 7.1 \\
Total & 42 & 100.0 \\
\hline
\end{tabular}

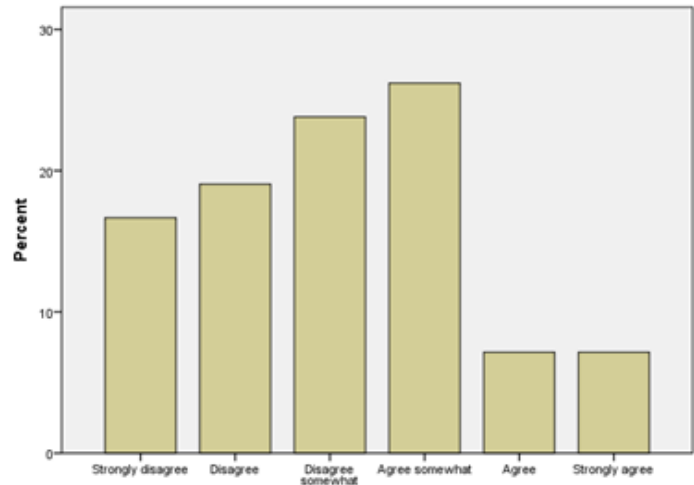

Our education system has not provided me with the language skills necessary to work abroad

\begin{tabular}{|c|c|c|c|}
\hline & & Frequency & Percent \\
\hline \multirow[t]{7}{*}{ Valid } & Strongly disagree & 5 & 11.9 \\
\hline & Disagree & 5 & 11.9 \\
\hline & Disagree somewhat & 2 & 4.8 \\
\hline & Agree somewhat & 12 & 28.6 \\
\hline & Agree & 14 & 33.3 \\
\hline & Strongly agree & 4 & 9.5 \\
\hline & Total & 42 & 100.0 \\
\hline
\end{tabular}

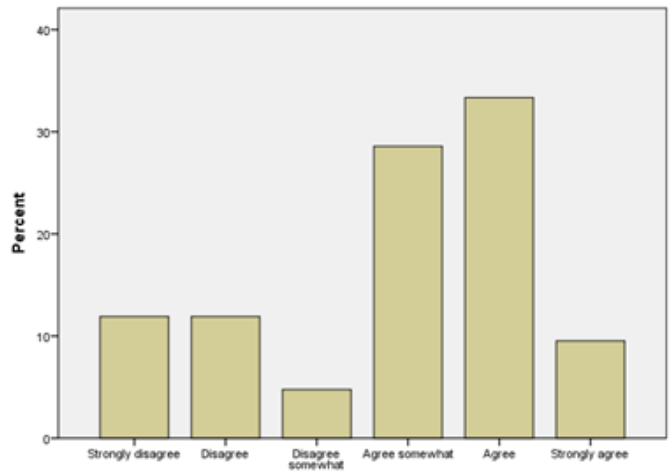

There is a lack of agencies which can help me find employment abroad

\begin{tabular}{|ll|r|r|}
\hline & Frequency & Percent \\
\hline Valid & Strongly disagree & 2 & 4.8 \\
& Disagree & 3 & 7.1 \\
Disagree somewhat & 3 & 7.1 \\
Undecided & 1 & 2.4 \\
Agree somewhat & 5 & 11.9 \\
Agree & 14 & 33.3 \\
Strongly agree & 14 & 33.3 \\
Total & 42 & 100.0 \\
\hline
\end{tabular}

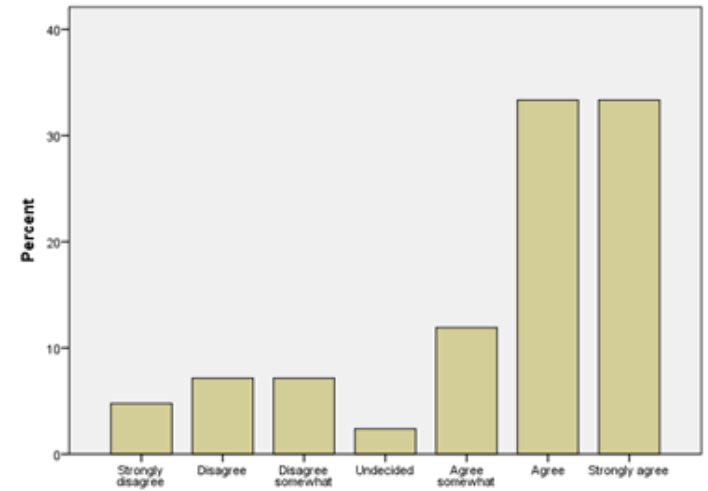

Survey on 20 nursing students:
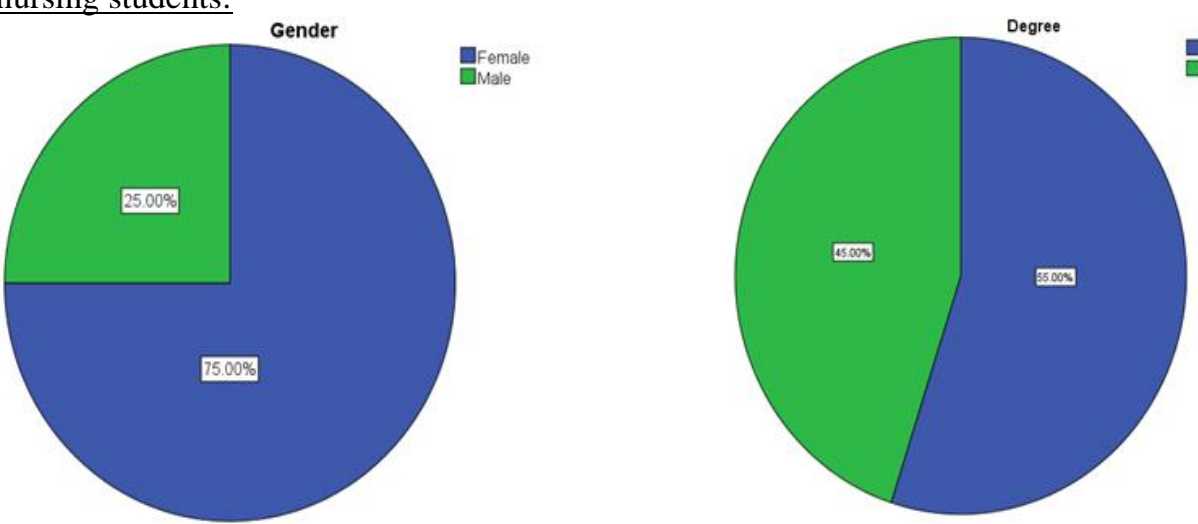
Do you think the education that you are receiving is appropriate for placement abroad?

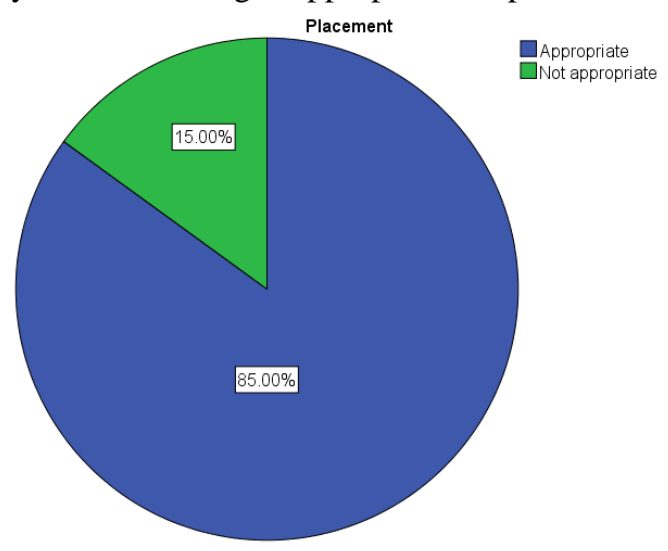

Reasons for joining the nursing profession

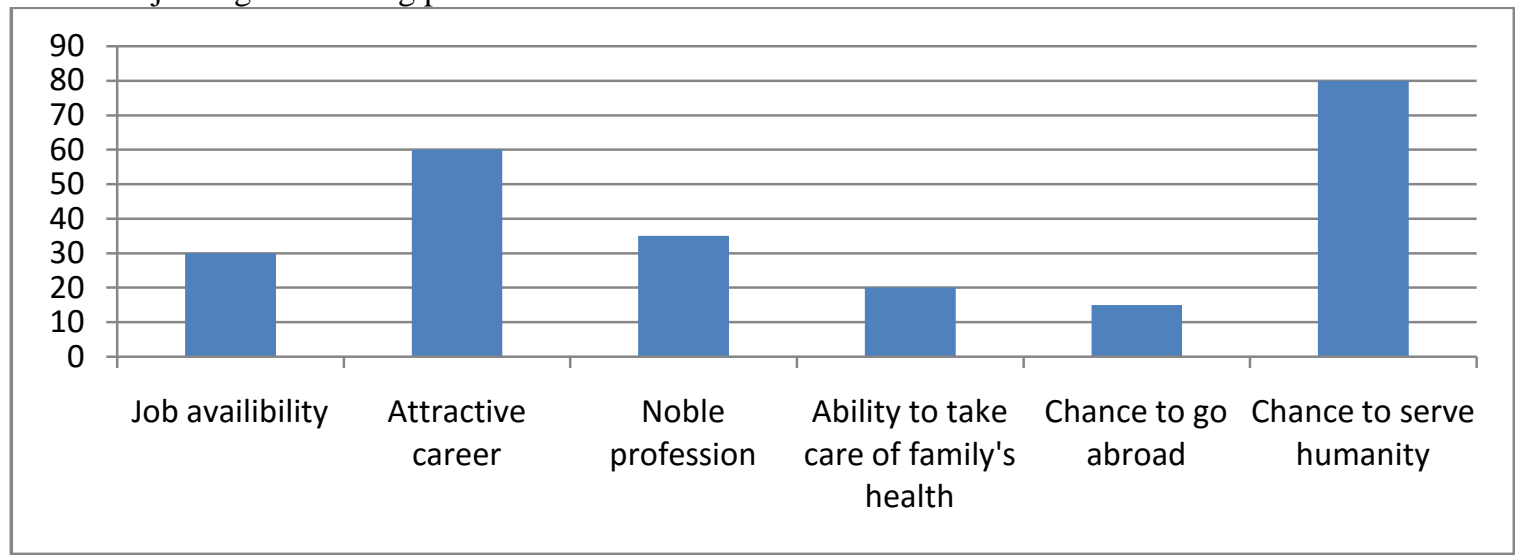

Barriers to joining the nursing profession in Bangladesh

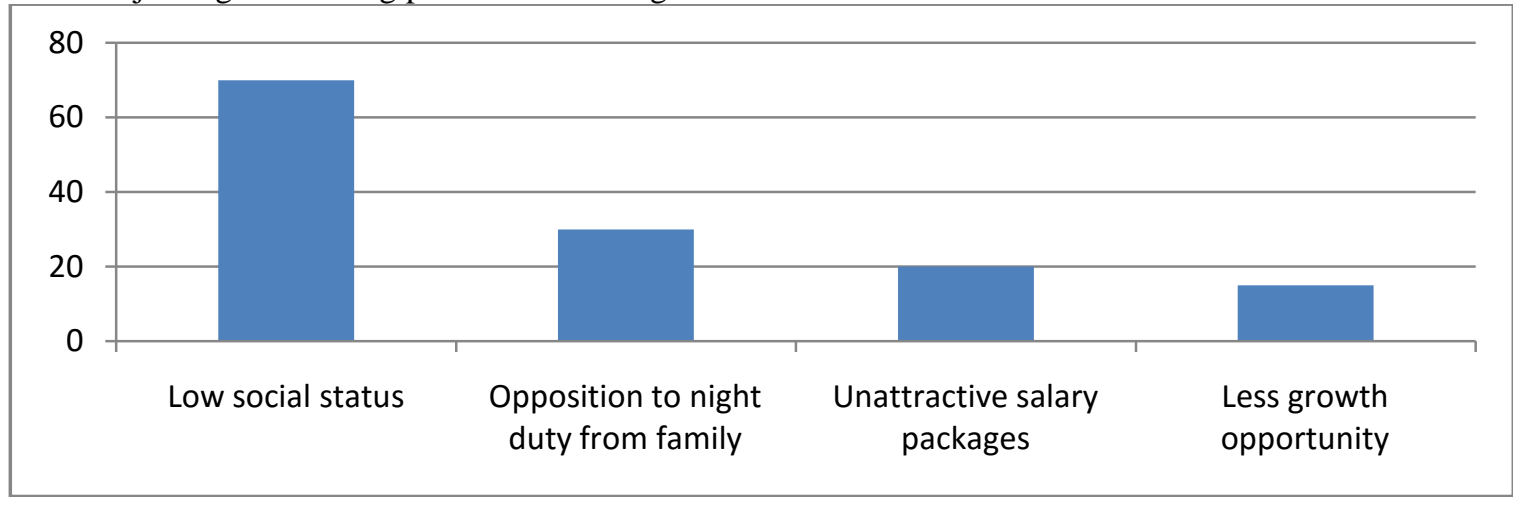

Weaknesses of nursing education in Bangladesh

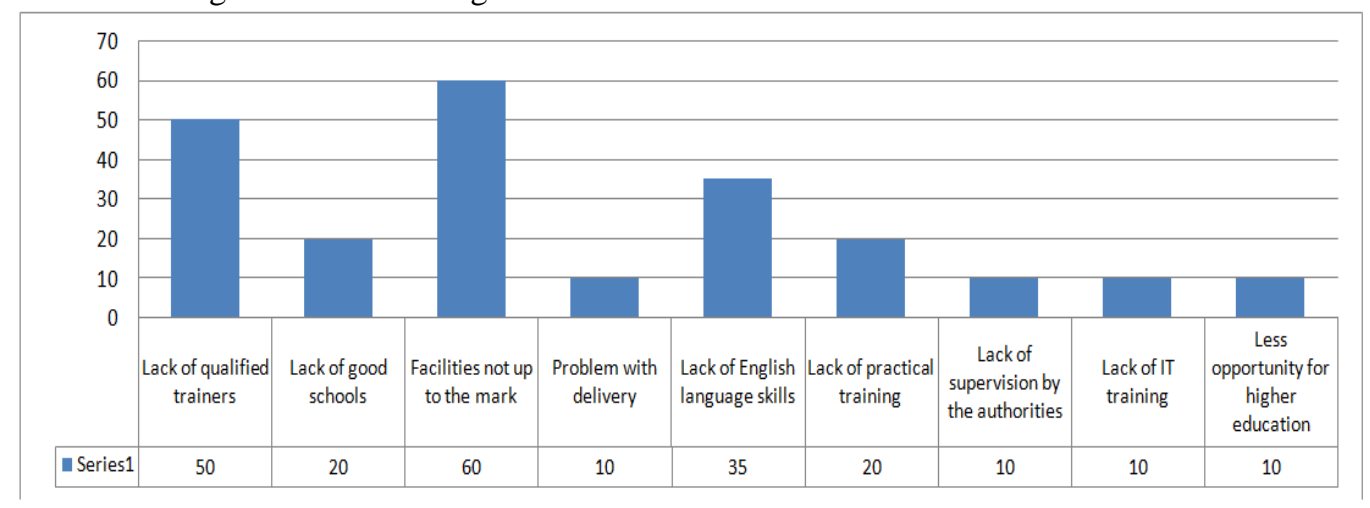


